\title{
Oceanodroma matsudairae obtained by 'ATLANTIS II' in the Indian Ocean; with anatomical note
}

\author{
Nagahisa Kuroda*
}

The Research Vessel, 'Atrantis II' of the Woods Hole Oceanographic Institution, Massachusetts, U.S.A., visited Japan during 25-30 September, 1965 after her International Indian Ocean Expedition. On this occasion, one of the two frozen specimens of Oceanodroma matsudairae obtained in Indian Ocean was forwarded to me for confirmation of record by the courtesy of Mr. Roger Pocklington, who was the chief ornithologist on board.

This storm-petrel breeds on N. Volcano I. (San Alessandro I. $25^{\circ} 25 \mathrm{~N}, 141^{\circ} 16 \mathrm{E}$ ) in the subtropical North Pacific from January to early June and has been known once from Sagami Bay, Japan, in May, 1921 (five males), but its summering waters were unknown. Recently, Mr. R. Bailey (1965) reports that this species was seen in Indian Ocean within $5^{\circ}$ of the equator from the Royal Research Ship 'Discovery'.

Here, I heartily express my thanks to Mr. R. Pocklington and other ornithologists on the 'Atlantis II' for their kindly letting me examine this rare specimen.

\section{The specimen}

The specimen is labelled as follows:

“Collected at $13^{\circ} 26^{\prime} \mathrm{S}, 120^{\circ} 19^{\prime} \mathrm{E}$ on 29 July, 1965, during R/V Atlantis II, Cruise 15"

This is a male, with small testicles, and in full molting.

Measurements: Weight $62 \mathrm{gm}$., Total length $248 \mathrm{~mm}$., Body length (shoulder to cloaca) $64 \mathrm{~mm}$., Wing extention $550 \mathrm{~mm}$., Wing bredth (secondaries) $80 \mathrm{~mm}$., Wing $180 \mathrm{~mm}$., Tail $104 \mathrm{~mm}$., Tail-fork $30 \mathrm{~mm}$., Tarsus $25.5 \mathrm{~mm}$., Culmen $15 \mathrm{~mm}$., Total wing area $340 \mathrm{~cm}^{2}$, One side primary area $88 \mathrm{~cm}^{2}$, One side secondary area $68 \mathrm{~cm}^{2}$, Tail area (spread 45 degrees) $80 \mathrm{~cm}^{2}$.

Molting: Both upper-and underparts are in molt, mottled with old and new feathers as shown by Fig. 1. All tail feathers are old, but wings are symmetrically molting.

Note: Another similar species $O$. tristrami also breeds on the same island October to April, but this species summers north to Japanese waters. Thus, from a breeding stock on the same island, matsudairae should have evolved as a warm adapted and blacker species migrating southward and tristrami a cold adapted bro.

* Yamashina Institute for Ornithology, Shibuya, Tokyo. 


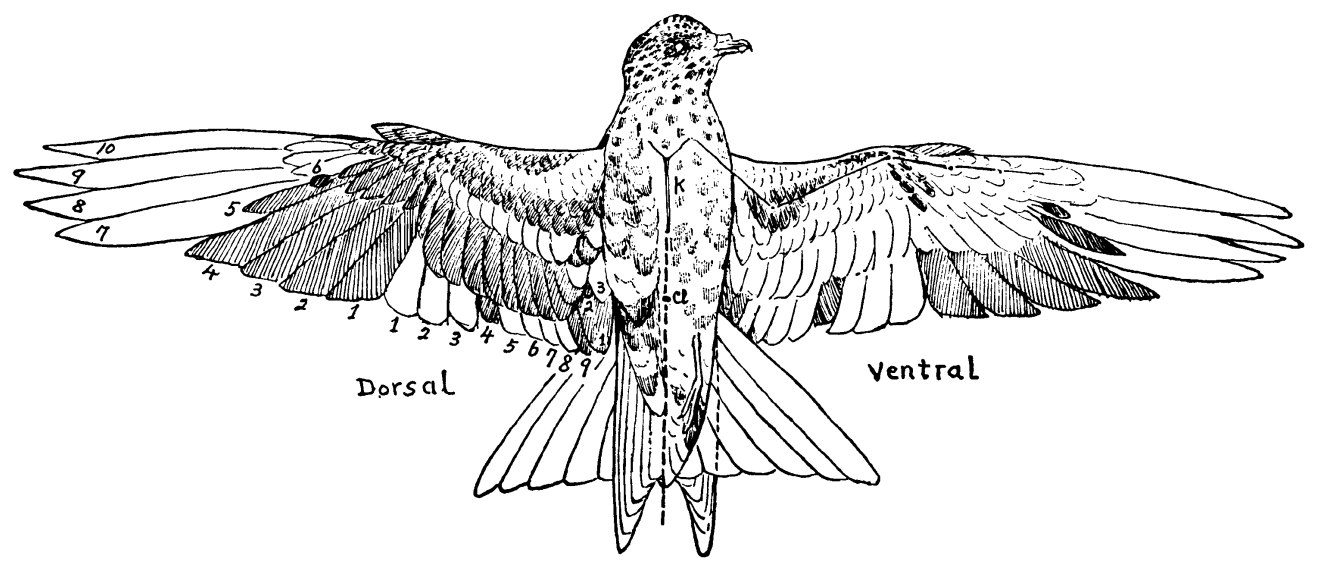

Fig. 1. $\uparrow$

Fig. 2. $\downarrow$

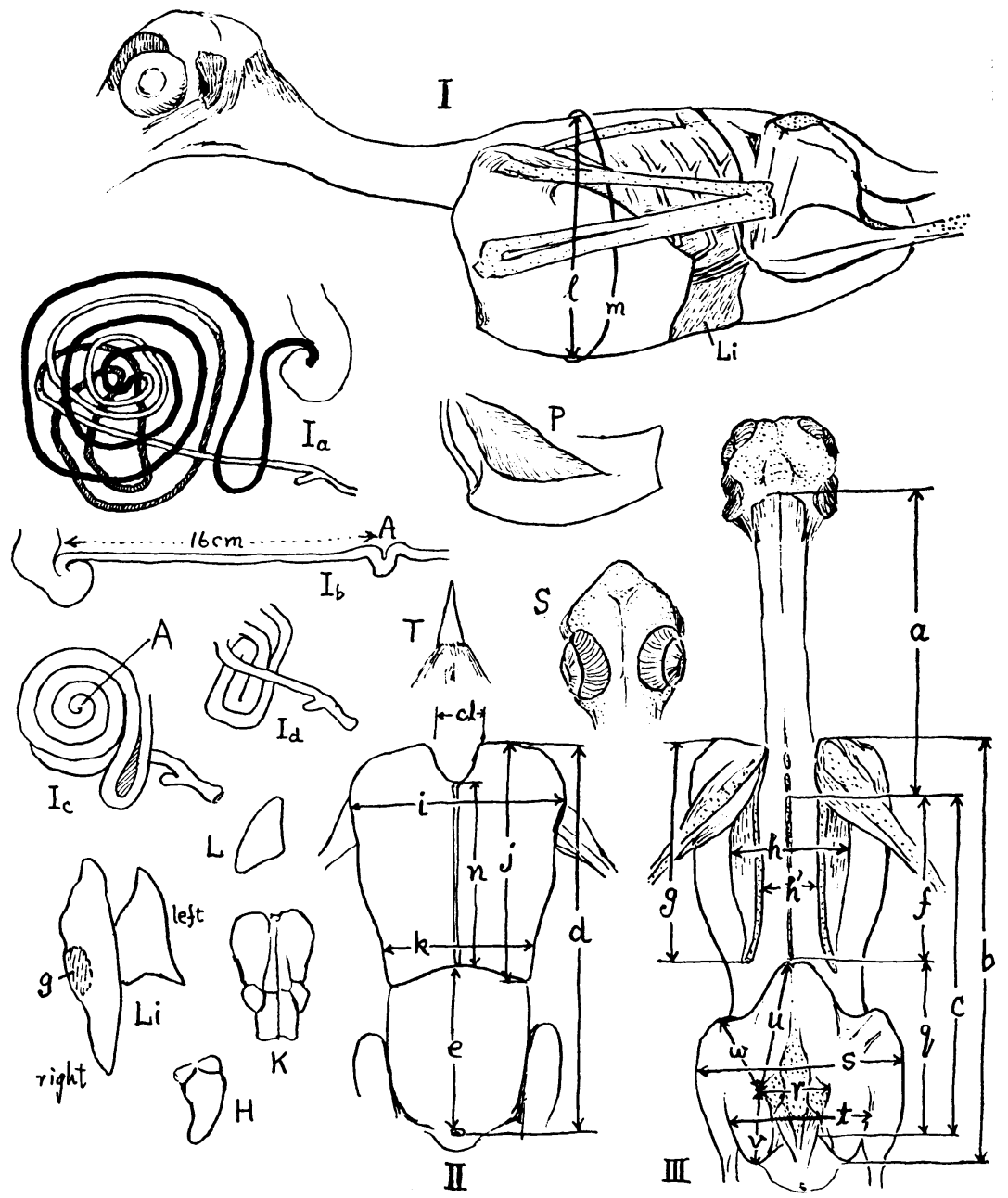

( 97$)$ 
wner species migrating northward. This probably caused discoincidence of their breeding seasons, and therefore reproductive segregation. Mastudairae has white base of the shafts of primaries which is said to be quite characteristic while flying (after Mr. Pocklington).

\section{Anatomical notes}

Some anatomical notes and measurements were taken which are as follows.

General body form: Measurements of skinned body were taken according to Kuroda (1961), as shown in Fig. 2, Tables $1 \& 2$.

Table 1. Measurements of skinned body (Ventral) (mm.)

\begin{tabular}{c|c|c|c|c|c|c|c|c}
\hline $\begin{array}{c}\text { Thoracic } \\
\text { depth } \\
(\mathrm{l})\end{array}$ & $\begin{array}{c}\text { Girth } \\
(\mathrm{m})\end{array}$ & $\begin{array}{c}\text { Trunk } \\
\text { length } \\
\text { (d) }\end{array}$ & $\begin{array}{c}\text { Pectoral } \\
\text { length } \\
\text { (i) }\end{array}$ & $\begin{array}{c}\text { Belly } \\
\text { length } \\
\text { (e) }\end{array}$ & $\begin{array}{c}\text { Anterior } \\
\text { pectoral } \\
\text { bredth } \\
\text { (i) }\end{array}$ & $\begin{array}{c}\text { Posterior } \\
\text { pectoral } \\
\text { bredth } \\
\text { (k) }\end{array}$ & $\begin{array}{c}\text { Keel } \\
\text { length } \\
\text { (n) }\end{array}$ & $\begin{array}{c}\text { Clavicular } \\
\text { width } \\
\text { (cl) }\end{array}$ \\
\hline 32 & 90 & - & 39 & 35 & 32 & 24 & 28 & 10.5 \\
\hline
\end{tabular}

Table 2. Measurements of skinned body (Dorsal)

\begin{tabular}{|c|c|c|c|c|c|c|}
\hline $\begin{array}{l}\text { Cervical } \\
\text { length } \\
\text { (a) }\end{array}$ & $\begin{array}{c}\text { Body } \\
\text { length } \\
\text { (b) }\end{array}$ & $\begin{array}{l}\text { Thoracic } \\
\text { length } \\
\text { (f) }\end{array}$ & $\begin{array}{c}\text { Scapular } \\
\text { length } \\
\text { (g) }\end{array}$ & $\begin{array}{l}\text { Dorsal } \\
\text { width } \\
\text { (h) }\end{array}$ & $\begin{array}{c}\text { Inner } \\
\text { scapular } \\
\text { distance } \\
\left(\mathbf{h}^{\prime}\right)\end{array}$ & $\begin{array}{l}\text { Dorso- } \\
\text { pelvic } \\
\text { length } \\
\text { (c) }\end{array}$ \\
\hline $52 *$ & - & 21 & - & 23 & 12 & - \\
\hline $\begin{array}{l}\text { Pelvic } \\
\text { length } \\
\text { (q) }\end{array}$ & $\begin{array}{c}\text { Outer tibial } \\
\text { bredth } \\
\text { (s) }\end{array}$ & $\begin{array}{c}\text { Hip bredth } \\
(t)\end{array}$ & $\begin{array}{l}\text { Pelvic } \\
\text { bredth } \\
(\mathrm{r})\end{array}$ & $\begin{array}{l}\text { Anterior } \\
\text { pelvic } \\
\text { length } \\
(\mathrm{u})\end{array}$ & $\begin{array}{l}\text { Posterior } \\
\text { hip length } \\
\text { (v) }\end{array}$ & $\begin{array}{c}\text { Femoral } \\
\text { length } \\
\text { (w) }\end{array}$ \\
\hline 23 & 28 & 20 & 11.5 & 15 & 9 & 20.5 \\
\hline
\end{tabular}

* Includes 2 cervico-dorsal vertebrae.

Muscular amount: The amount of muscles of pectoral and pelvic appendages were measured (Table 3).

Digestive tract: The intestinal coil is of cyclocoelous type (Fig. 2, I ) and the coiling is reversed just at the middle point. The coecum is an unpaired single nod and the tongue is of simple shape (Fig. 2). The measurements are given in Table 4.

Fig. 1. Wing spread form and showing molting pattern (on 29 July). White part shows old and hatched part new feathers. Note the growing primaries 5 and 6 (also its covert), secondaries 4 and 9, and tertiaries 1 and 2. The molting is symmetrical on both wings (left wing shown).

Fig. 2. Body form and some anatomical sketches. I (lateral), II (ventral) and III (dorsal) show body form and measurement items. Ia, b, c, d: Intestinal convolution, with a single coecum ; P: Size of M. subcoracoideus; T: Tongue form; S: Showing salt glands; L : Lung form; Li: Liver; g: Gall bladder; K: Kidney; H: Heart form (long type) 
Table 3. Weights of pectoral and leg muscles (gm.) of one side

\begin{tabular}{c|c|c|c|c|c|c}
\hline \multicolumn{3}{c|}{ Large pectoralis* } & $\begin{array}{c}\text { Small } \\
\text { Pectoralis }\end{array}$ & $\begin{array}{c}\text { Thigh } \\
\text { muscles }\end{array}$ & $\begin{array}{c}\text { Tibial } \\
\text { muscles }\end{array}$ \\
\hline Lateralis & Proprius & Profundus & Total & 0.5 & 0.5 & 0.6 \\
\hline 0.9 & 1.6 & 0.7 & 3.2 & 0.5 & 0.5 \\
\hline
\end{tabular}

* For muscular layers cf. Kuroda (1960).

Table 4. Measurements of the digestive tract (mm. \& gm.)

\begin{tabular}{c|c|c|c|c|c}
\hline \multirow{2}{*}{ Tongue } & $\begin{array}{c}\text { Weight of } \\
\text { oesophagus \& } \\
\text { proventriculus }\end{array}$ & \multicolumn{2}{|c|}{ Intestine } & $\begin{array}{c}\text { Coecum } \\
\text { length }\end{array}$ & $\begin{array}{c}\text { Rectum } \\
\text { length }\end{array}$ \\
\cline { 2 - 5 }- & $4.9^{*}$ & 3.0 & 320 & $\begin{array}{c}\text { Sengle } \\
4\end{array}$ & 12 \\
\hline
\end{tabular}

* With milky content and one small stomach stone.

Table 5. Measurements of various organs (mm. \&. gm.)

\begin{tabular}{|c|c|c|c|c|c|c|}
\hline \multirow{3}{*}{$\begin{array}{l}\text { Nasal salt } \\
\text { gland }\end{array}$} & \multicolumn{5}{|c|}{ Liver } & \multirow{3}{*}{$\begin{array}{c}\text { Lung } \\
\text { Size }\end{array}$} \\
\hline & \multicolumn{2}{|c|}{ Left } & \multicolumn{2}{|c|}{ Right } & \multirow{2}{*}{$\begin{array}{c}\text { Total } \\
\text { Weight }\end{array}$} & \\
\hline & Size & Weight & Size & Weight & & \\
\hline Width 6 & $25 \times 17$ & 1.2 & $30 \times 10$ & 1.2 & 2.4 & $20 \times 13$ \\
\hline Lung & \multicolumn{2}{|c|}{$\begin{array}{c}\text { Heart } \\
\text { (ventricle) }\end{array}$} & \multicolumn{3}{|c|}{ Kidney } & \\
\hline Weight & Size & Weight & Length & Width & Weight & \\
\hline 0.5 & $17 \times 11$ & 0.6 & - & $\begin{array}{l}\text { Anter. } 18 \\
\text { Poster. } 9\end{array}$ & 1.1 & \\
\hline
\end{tabular}

Table 6. Relative weights (in \%) of various organs and parts for body weight

\begin{tabular}{c|c|c|c|c|c}
\hline Liver & Lung & $\begin{array}{c}\text { Heart } \\
\text { (ventricle) }\end{array}$ & $\begin{array}{c}\text { Oesophagus \& } \\
\text { proventriculus }\end{array}$ & Intestine & Kidney \\
\hline 3.87 & 0.806 & 0.968 & 7.90 & 4.84 & 1.77 \\
\hline \multicolumn{2}{l|}{ Pectoralis (One side) } & Total & Thigh & Tibial & Total \\
\hline Large & Small & 5.97 & 0.8 & 0.9 & 1.77 \\
\hline
\end{tabular}

Other organs: The measurements and forms of some organs are shown in Table 5. The nasal salt glands are developed for skull size. There is a large gallbladder in the right lobe of the liver. The lung is small and the heart is long 
type. The kidney is relatively large. The relative weights for body weight of various organs are shown in Table 6.

\section{References}

Bailey, R. 1965. Second interim report on the International Indian Ocean Expedition. Ibis $107(1): 133-134$

Kuroda, N. h. 1960. On the pectoral muscles in birds. Misc. Rep. Yam. Inst. 2 (No. 14): 50-59 (With Suppl. note in ibid. No. 16:66, 1961).

Kuroda, N. h. 1961. Analysis of three adaptive body forms in the Steganopodes, with note on pectoral muscles. Misc. Rep. Yam. Inst. 3(1) (No. 16): 54-66.

Additional note : After finishing this paper, I sent my specimen to Dr. G. E. Watson, Smithsonian Institution, according to his request to compare it with his other Atlantis II's specimen. As the result, he confirmed that the both are matsudairae although his bird had the longest $(29 \mathrm{~mm})$ and mine the shortest $(25 \mathrm{~mm})$ tarsi for the species. For reference, I show here the tarsus and wing measurements of 47 males and 44 females preserved in Yamashina Institute (Momiyama collection) in Table 7.

Table 7. Measurements of tarsus and wing of $O$. matsudairae from San Alessandro I. (Momiyama coll.)

a. Tarsus

\begin{tabular}{c|c|c|c|c|c|c}
\hline Tarsus (mm) & $25-$ & $26-$ & $27-$ & $28-$ & 29 & Mean \\
\hline 47 하 & 1 & 20 & 16 & 9 & 1 & 22.6 \\
44 와 우 & 5 & 6 & 22 & 8 & 3 & 27.0 \\
Total & 6 & 26 & 38 & 17 & 4 & 26.8 \\
\hline
\end{tabular}

b. Wing

\begin{tabular}{c|c|c|c|r|r|r|r}
\hline Wing (mm) & 178 & $180-181$ & $182-184$ & $185-187$ & $188-190$ & $191-194$ & Mean \\
\hline 47 오 & 1 & 2 & 10 & 16 & 9 & 9 & 186.8 \\
44 우 우 & & 1 & 6 & 14 & 16 & 7 & 187.5 \\
Total & 1 & 3 & 16 & 30 & 25 & 16 & 187.1 \\
\hline
\end{tabular}

My specimen with fresh feathers is distinctly blacker than numerous examples from the breeding island obtained during 1928-1935 which are similarly faded to brown by long preservation and molting stage is difficult to confirm. The Smithsonian specimen is, according to Dr. Watson, 'somewhat duller and a little browner' than mine, 'but not as brown as specimens collected in 1929.' The dates and number of specimens of Momiyama collection from the breeding island (at Ishino and Nishi villages) are shown in Table 8 , and it may be said that although some may remain offshore around the breeding island, it may well be that they migrate to southern seas. 
Table 8. Number of specimens of $O$. matsudairae by month obtained on San Alessandro I. (Momiyama coll.)

\begin{tabular}{l|r|r|r|r|r|r|r|r|r}
\hline Month & J & F & M & A & My & J & Jy & Au & Total \\
\hline & 5 & 1 & 14 & 12 & 11 & & 3 & 1 & 47 \\
Juv. & 2 & 2 & 7 & 14 & 13 & 5 & 1 & & 44 \\
\end{tabular}

Note: Beside these, there is a specimen from S. Volcano I. (San Augustino I.) obtained on April 1, 1936.

\title{
クロウミッバメのインド洋記録と解剖所見
}

\author{
黒田長 久
}

クロウミツバメはオーストンウシッバメと同様北硫黄島に 1-6 月繁殖するがこの海域以外では従来相 模湾で 5 月に得られたにすぎない。今回 1965 年 9 月東京湾に寄港した北米のインド洋調査船第 II アトラ ンティス号の Pocklington 氏の御好意でインド洋で得られた 2 標本のらち 1 個体の寄贈を受けた。北硫黄 島の繁殖期は両種で約 2 ケ月の差があり, クロウミッバメは南にオーストンウミッバメは北方日本近海に 渡る。とれは恐らく同島に繁殖した原個体群に温度適応の異なる群を生じ，渡りの方向が反対となり，従 って繁殖期もずれ, 濃色のクロウミツバメ（初列風切の羽軸基部白く, 飛翔時も識別できるといら）と褐色 のオーストンウシッバメの種分化をなしたのであろら。標本につき換羽や解剖所見を附記した。な拉，他 の 1 標本はスミソニア研究所の Watson 博士に送られた。山階研所蔵の繁殖地の粐山標本の測定につんて も附記した。 